\title{
Medicinal and Environmental Indicator Species of Utricularia from Montane Forest of Peninsular Malaysia
}

\author{
Noorma Wati Haron ${ }^{1}$ and Ming Yee $\mathrm{Chew}^{2}$ \\ ${ }^{1}$ Institute of Biological Sciences, Faculty of Science, University of Malaya, 50603 Kuala Lumpur, Malaysia \\ ${ }^{2}$ Kepong Herbarium, Forest Research Institute Malaysia, 52109 Kepong, Selangor, Malaysia \\ Correspondence should be addressed to Noorma Wati Haron, noorma@um.edu.my
}

Received 12 October 2011; Accepted 7 December 2011

Academic Editors: S.-M. Chaw, S. C. Land, and L. A. Videla

Copyright ( 2012 N. W. Haron and M. Y. Chew. This is an open access article distributed under the Creative Commons Attribution License, which permits unrestricted use, distribution, and reproduction in any medium, provided the original work is properly cited.

\begin{abstract}
The carnivorous Utricularia (Lentibulariaceae) is a small herb of multifarious wet habitats worldwide. Eleven of the 14 Peninsular Malaysian species range into the mountains. Distribution, disturbance adaptability and collection frequency were used to formulate their commonness category. Common (U. aurea, U. bifida, and U. minutissima) and fairly common (U. gibba and U. uliginosa) species are mostly lowland plants that ascend to open montane microhabitats, while the fairly common (U. striatula), narrow-range (U. caerulea pink form and U. involvens), rare (U. furcellata and U. scandens), and endemic (U. vitellina) species are restricted to mountainous sites. Common species that colonise dystrophic to oligotrophic man-made sites in late succession could serve as predictors for general health and recovery of wet habitats. Rarer species are often locally abundant, their niches situated around pristine forest edges. When in decline, they indicate the beginning of problems affecting the forest. Utricularia is reportedly nutritious, mildly astringent, and diuretic. Preadapted to nutrient-poor, waterlogged soils, $U$. bifida is suitable as an alternative for small-scale herb cultivation on low $\mathrm{pH}$, wet poor soils usually deemed not suitable for any crops.
\end{abstract}

\section{Introduction}

Almost half of the approximately 500 carnivorous angiosperm species are from the genus Utricularia L., the bladderworts (family Lentibulariaceae), which has a cosmopolitan distribution in multifarious wet habitats worldwide [1]. Peninsular Malaysia is home to 14 Utricularia species, 11 (Table 1) of which ranges extend into the mountainous habitats while five are almost restricted to mountains. The body plan of Utricularia is peculiar, plastic, and unique among flowering plants. It is capable of changing its resources investment to match varying water chemistry, irradiance level, and prey availability $[2,3]$.

The cost-benefit model by Givnish et al. [4] showed that carnivorous plants generally prefer sunny, moist, lownutrient habitats with low $\mathrm{pH}$ (3-7). Many aspects of the ecology and carnivorous habit of Utricularia have been researched previously [5-7]. One third of Peninsular Malaysian Utricularia are habitat specialists, that is, requiring strict edaphic conditions and niches to survive, another third are habitat generalists that are found in many sites and are suited to live in many types of wet microhabitats but are rarely found in heavily disturbed sites, while three species are common pioneers of open and wet habitats [8]. This study investigated the montane microhabitat characteristics of Utricularia in Peninsular Malaysia, documenting their commonness, and establishing their potential as environmental indicators and as medicinal species.

\section{Materials and Methods}

Baseline distribution information from herbaria specimens was tabulated followed by field surveys to record microhabitat physical and biotic details. Herbarium specimens examined and vouchers collected during field surveys are listed in Table 2. In Peninsular Malaysia, the montane forest formation includes both the lower ((600-)800-1,500 m) and upper $(>1,500 \mathrm{~m})$ montane forest [10]. Here, steeply hilly riverine sites above $300 \mathrm{~m}$ are also included for discussion. Montane diversity hotspots, localities with rare species, and 
Table 1: General habit of Peninsular Malaysian Utricularia found in mountainous sites.

\begin{tabular}{lcccc}
\hline Species & General habit & Leaf & Flower & Fruit \\
\hline U. aurea & Free floating & Much divided & Yellow & Pendent \\
U. bifida & Terrestrial/semiaquatic & Filiform & Yellow & Enclosed by calyx \\
U. caerulea & Terrestrial/semiaquatic & Narrow obovate & Pink & Crowded near tip \\
U. furcellata & Lithophytic/terrestrial & Rosette, spatulate & Pink/white & Calyx bonnet-like \\
U. gibba & Free floating & Divided, filiform & Yellow & Minute, globular \\
U. involvens & Terrestrial/semiaquatic & Ribbon-like & Yellow, twines & Enclosed by calyx \\
U. minutissima & Terrestrial/semiaquatic & Filiform & Purple/white & Minute, ellipsoid \\
U. scandens & Terrestrial & Filiform & Yellow, twines & Enclosed by calyx \\
U. striatula & Lithophytic/epiphytic & Rosette, spatulate & Pink/white & Calyx bonnet-like \\
U. uliginosa & Terrestrial/semiaquatic & Ribbon-like & Bluish & Enclosed by calyx \\
U. vitellina & Terrestrial, on moss & Ribbon-like & Yellow & Enclosed by calyx \\
\hline
\end{tabular}

Table 2: Peninsular Malaysian Utricularia specimens from mountainous areas examined.

\begin{tabular}{|c|c|}
\hline Species & Collector, specimen number (Herbarium of deposit) \\
\hline U. aurea & Burkill, HMB2327 (L, SING); Purseglove, P4293 (K, L, SING) \\
\hline U. bifida & $\begin{array}{l}\text { Chew, FRI53756 (K, KEP); Chew, FRI67377 (DUB, K, KEP); Kiew, RK2232 (KEP); Siti-Munirah, FRI55252 } \\
\text { (KEP) }\end{array}$ \\
\hline U. caerulea & $\begin{array}{l}\text { Burkill, HMB } 3305 \text { (K, L, SING); Chew, FRI63329 (DUB, K, KEP, TAIF); Ridley, } 10091 \text { (SING); Ridley, s.n. } \\
\text { (SING); Robinson, } 6112 \text { (K, SING); Spare, } 2925 \text { (SING); Spare, } 3667 \text { (SING); Wight, } 2418 \text { (L) }\end{array}$ \\
\hline U. furcellata & Chew, FRI53603 (KEP) \\
\hline U. gibba & Spare, 3615 (SING) \\
\hline U.involvens & $\begin{array}{l}\text { Abdul Kadir SF19763 (L, SING); Burkill, HMB } 3306 \text { (K, SING); Chew FRI63280 (KEP, K, DUB, TAIF); Ding, } \\
783 \text { (K, L); Flippance, s.n. (SING); Kiew, RK4859 (SING); Mohd. Haniff } 5174 \text { (SING); Mohd. Haniff, SF4736 (L, } \\
\text { SING); Ng, FRI27117 (KEP); Reilly, } 155 \text { (K); Ridley, s.n. (SING); Robinson, HCR } 5959 \text { (K, SING); Symington, } \\
\text { FMS46881 (KEP); Anonymous, SFN35814 (SING) }\end{array}$ \\
\hline U. minutissima & $\begin{array}{l}\text { Chew, FRI60205 (KEP); Chew, FRI63300 (K, KEP); Chew, FRI63328 (DUB, KEP); Chew, FRI65651 (KEP); } \\
\text { Chew, FRI67378 (DUB, K, KEP); Hislop, s.n. (SING); Holttum, } 20645 \text { (SING); Kiew, RK2438 (SING); Kloss, } \\
12132 \text { (SING); Kloss, } 12206 \text { (L, SING); Mohd. Haniff, } 7994 \text { (K, L, SING); Ridley, } 16111 \text { (K, SING); Ridley, } 16112 \\
\text { (K, SING); Ridley, s.n. (L); Ridley, s.n. (SING); Robinson, } 5955 \text { (K, SING); Spare } 3664 \text { (K, L, SING); Spare, } 3665 \\
\text { (SING); Symington, FMS37774 (KEP); Symington, } 28840 \text { (SING); Kiew, RK4080 (K, KEP); Wilkie, FRI52872 (E, } \\
\text { KEP); Wong, W171 (KEP); Wray, } 5447 \text { (L, SING); }\end{array}$ \\
\hline U. scandens & Chew, FRI63327 (KEP, K, DUB); Ridley, s.n. (L, SING) \\
\hline U. striatula & $\begin{array}{l}\text { Burkill, HMB3362 (K, L); Chew, FRI58683 (KEP, SING); Chew, FRI58685 (KEP); Chew, FRI60221 (KEP); Chew, } \\
\text { FRI65653 (KEP); Chew, FRI67363 (KEP, K); Chew, s.n. (KEP); Curtis, s.n. (SING); Kiew, RK2434 (KEP); Kloss, } \\
12131 \text { (SING); Kloss, } 12214 \text { (SING); Lim, FRI56349 (E, KEP, L, SAN, SING); Ridley, s.n. (SING); Robinson, } 5970 \\
\text { (K); Robinson, } 5976 \text { (SING); Spare, } 3663 \text { (SING); Stone, } 6394 \text { (L); Wight, } 2419 \text { (L); Holttum, } 21595 \text { (SING); } \\
\text { Kiew, RK230 (SING); Mohd. Haniff, } 7883 \text { (SING); Ridley, } 16111 \text { (K, SING); Seimund, ES170 (SING); Wilkie, } \\
\text { FRI52874 (E, KEP, SAN); Wong, W92 (KEP); Wray, } 3880 \text { (SING); Wray, } 4146 \text { (SING); Yapp, } 436 \text { (K) }\end{array}$ \\
\hline U.uliginosa & $\begin{array}{l}\text { Chew, FRI58682 (KEP, SING); Chew, FRI58684 (KEP); Chew, FRI } 63326 \text { (DUB, K, KEP, TAIF); Chew, FRI } 63285 \\
\text { (DUB, K, KEP, SING); Hislop, s.n. (L, SING); Rao, } 90 \text { (L); Ridley, s.n. (SING); Spare, } 3662 \text { (SING); Symington, } \\
\text { FMS37773 (KEP) }\end{array}$ \\
\hline U. vitellina & Chew, FRI60222 (KEP); Chew, FRI63684 (KEP); Ridley 16113 (SING) \\
\hline
\end{tabular}

Herbaria code: $\mathrm{DUB}=$ Dublin, $\mathrm{K}=\mathrm{Kew}, \mathrm{KEP}=$ Kepong, $\mathrm{L}=$ Leiden, $\mathrm{SING}=$ Singapore, TAIF = Taipei.

potential sites with suitable habitats for Utricularia were targeted. An empirical commonness category was formulated based on the distribution of each species in Peninsular Malaysia, its adaptability to disturbance and collection frequency that indicates rarity (Table 3 ). The two subcategories of common species include those distributed throughout Peninsular Malaysia; on the opposite scale narrowly ranging and rare species are only found in a few localities.

\section{Results and Discussion}

Utricularia species occupy a variety of microhabitats in mountainous areas (Table 4). Utricularia aurea, U. bifida (Figure 1), and U. minutissima are the three most common species throughout Peninsular Malaysia, while U. gibba, $U$. striatula, and $U$. uliginosa are from the fairly common category, found mainly in natural sites throughout Peninsular 
TABle 3: Commonness criteria* for Utricularia of Peninsular Malaysia.

\begin{tabular}{lccc}
\hline Category & $\begin{array}{c}\text { Distribution in } \\
\text { Peninsular Malaysia }\end{array}$ & $\begin{array}{c}\text { Disturbance } \\
\text { adaptability }\end{array}$ & $\begin{array}{c}\text { Collection } \\
\text { frequency }\end{array}$ \\
\hline $\begin{array}{l}\text { Common } \\
\text { Fairly } \\
\text { common }\end{array}$ & Throughout & $\begin{array}{c}\text { Common in } \\
\text { man-made site }\end{array}$ & $>40$ \\
$\begin{array}{l}\text { Narrow } \\
\text { range } \\
\text { Rare }\end{array}$ & $<3$ localities & $\begin{array}{c}\text { Mostly in rarely } \\
\text { disturbed site }\end{array}$ & $10-20$ \\
\hline
\end{tabular}

${ }_{\mathrm{f}}$ based on number of herbaria specimens.

*adapted to suit the geographical range and demographic details on population of the Taxon Data Information Sheets modified from the IUCN Red list assessment questionnaire, as recommended by the Malaysia Plant Red List guidebook [9].

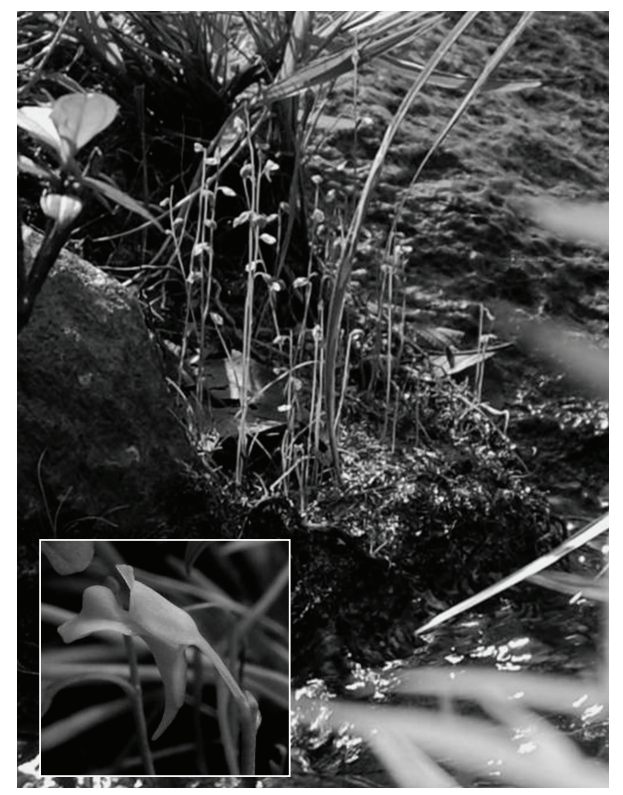

FIGURE 1: Utricularia bifida-the most common terrestrial species often found along waysides.

Malaysia. Except for U. striatula, they are mostly lowland plants, ascending the mountain along streams, heath, and man-made, ephemeral wetlands. Utricularia striatula is essentially a montane species but descends to the lowland along streams and is restricted to perpetually wet and humid microhabitats. U. caerulea (pink form) and $U$. involvens are narrow-range taxa. There are three rare species, $U$. furcellata and $U$. scandens are each found in a single locality, while U. vitellina (Figure 2) is found in two localities. All these narrow-range and rare taxa are restricted to mountainous sites.

The distribution pattern of the genus (Figure 3) illustrates that diversity hotspots are centred in small isolated mountain massifs. Gunung Jerai, Kedah, topped the list with seven species, followed by Gunung Ledang, Johor with five species. The endemic $U$. vitellina is restricted to one type of

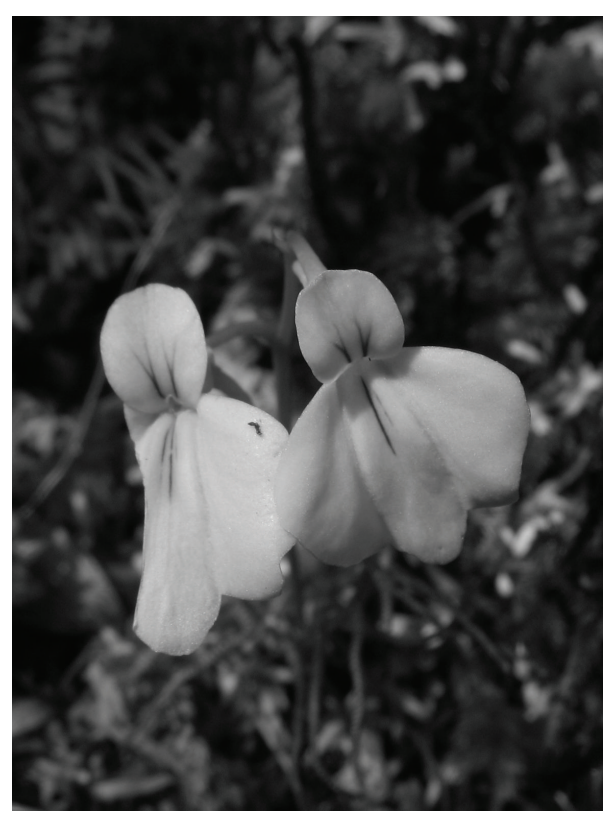

Figure 2: Utricularia vitellina-the endemic montane species of Peninsular Malaysia.

microhabitat, that is, peaty and mossy stream banks within the lower and upper montane forest, on the two highest peaks in Peninsular Malaysia, namely, Gunung Korbu and Gunung Tahan. The rare U. furcellata is confined to a small heath-like sandy patch on Gunung Ayam, Kelantan, while $U$. scandens to the stony heath on Gunung Mering, Johor. Mountains with large, open, montane heath, or swamps harvest extremely large Utricularia populations; for example, the padang (rock field) of Gunung Tahan, Pahang, and the Sphagnum bog of Gunung Stong, Kelantan.

3.1. Potential as Environmental Indicator. The presence of common pioneer species (Utricularia aurea and U. bifida) indicates past disturbance in a habitat, such as that demonstrated in a paleonological study, with the first appearance of $U$. aurea pollen coinciding with the arrival of aborigines in Tasik Bera, Pahang [11]. The common or fairly common species may colonise pond edges and shallowly inundated patches in well-established gardens, constructed wetlands, or waysides in late succession. They are, however, absent from heavily worked agricultural land or sites that are observably affected by severe chemical or organic waste runoffs and siltation. A few species are cultivated by local as well as international enthusiasts as curiosity plant, hence their requirements for dystrophic to oligotrophic conditions have been documented. Many mountainous areas in Peninsular Malaysia are being developed as recreational destinations with extensive landscaping, while large stretches are sought after by the agricultural sector to cultivate cash crops that need a more temperate environment to grow. The presence of common Utricularia species in the suburban waysides can therefore be used as a rough prediction for water trophicity, succession stages, and the general health of the regenerating secondary patches. 
TABle 4: Utricularia of Peninsular Malaysia montane microhabitat details.

\begin{tabular}{|c|c|c|c|}
\hline Species & Montane microhabitat type & Altitude (m a.s.l.) & $\mathrm{pH}$ range \\
\hline \multicolumn{4}{|c|}{ Common and fairly common species } \\
\hline U. aurea & Reservoir or man-made ponds & $0-1,231$ & $3-7$ \\
\hline U. bifida & Wayside puddles, damp sandy spot & $4-1,190$ & $4-6$ \\
\hline U. gibba & Reservoir or ponds & $0-1,577$ & $3-5.5$ \\
\hline U. minutissima & Heaths, stream banks, damp spots, puddles & $1-2,180$ & $4-6$ \\
\hline U. striatula ${ }^{\Delta}$ & Wet/dripping rock faces/tree trunks/branches, mossy mounds & $150-2,180$ & $3.5-5.5$ \\
\hline U. uliginosa & Stream beds, Sphagnum bogs & $1-1,362$ & $3.5-6.5$ \\
\hline \multicolumn{4}{|c|}{ Narrow Range Species } \\
\hline U. caerulea & Stream banks & $1-901$ & $4.5-6$ \\
\hline U. involvens ${ }^{\Delta}$ & Waterfalls, damp grassy spots & $750-1,189$ & $3.5-6$ \\
\hline \multicolumn{4}{|c|}{ Rare Species } \\
\hline U. furcellata ${ }^{\Delta}$ & Heaths & 1,500 & c. 5 \\
\hline U. scandens ${ }^{\Delta}$ & Stony heaths, stream banks, damp grassy spots & $380-387$ & c. 5 \\
\hline U. vitellina $\triangle$ & Stream banks, mountain tops well-aerated damp mossy mounds & $1,526-2,080$ & $3.5-5$ \\
\hline
\end{tabular}

$\mathrm{m}$ a.s.l. = metre above sea level.

${ }^{\triangle}$ Essentially mountain species in hilly microhabitats above $300 \mathrm{~m}$ altitude.

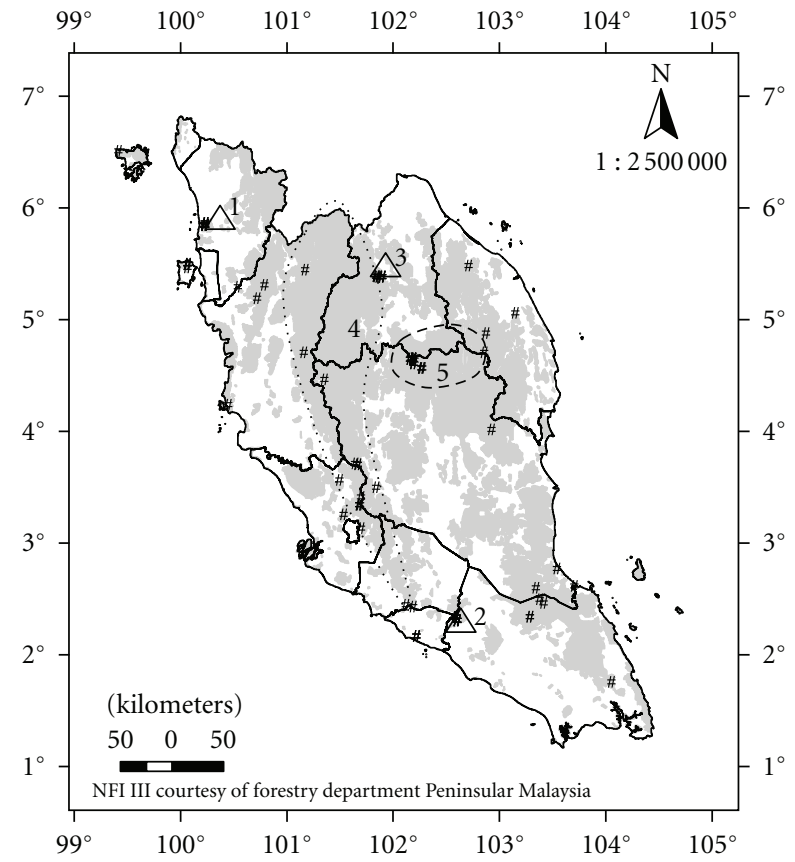

$$
\begin{array}{cll}
\text { Montane diversity hotspots: } & \text { Location based on } \\
\triangle 1 \quad \text { Gn. Jerai, Kedah: } 7 \text { spp. } & \# \text { Herbarium specimen(s) } \\
\triangle 2 \quad \text { Gn. Ledang, Johor: } 5 \mathrm{spp} . & \square \text { Forest cover as in national } \\
\triangle 3 \quad \text { Gn. Stong, Kelantan: } 4 \mathrm{spp} . & \text { Forest inventory III } \\
\ldots \ldots 4 & \text { Main Range: endemic sp. } & (1991-1993) \\
---5 \text { Gn. Tahan: endemic sp. } & \\
\text { Gn. }=\text { Gunung, mountain in Malay } &
\end{array}
$$

FIgURE 3: Distribution of Utricularia in mountainous habitats in Peninsular Malaysia ( $\geq 300 \mathrm{~m}$ a.s.l.).

Narrow-range and rare species occupy wet montane habitats with acidic soil ( $\mathrm{pH}$ range 3.5-6), either along streambeds ( $U$. caerulea, $U$. involvens, and $U$. vitellina) or heath (U. furcellata and U. scandens). Under pristine conditions, these species are often locally abundant. Despite that, rare species historically recorded from sites that were later affected by heavy hiking traffic, recreation amenity development, drying-up effect from loss of vegetation in the surrounding area, and flash-floods often did not survive this microhabitat loss. They are therefore indicators of environmental degradation. Parks and protected forest areas are continuously being used by the public for recreational and educational purposes. In order to achieve their species conservation roles while allowing for controlled use within their carrying capacities, these areas need to be monitored periodically for their general health. As Utricularia occupies niches that are nestled around the edges of the forest but rarely within it, their decline could herald the beginning of major problems that would affect the rest of the forest communities if left unchecked.

3.2. Potential as Medicinal Crop. Utricularia is recorded to be edible and high in nutrients. Some species used as folk remedies are mildly astringent and diuretic. U. caerulea is used to dress wounds while $U$. bifida is used to treat urinary diseases. Although yet to be widely researched, the medicinal potential of this species-rich genus is immense. In Peninsular Malaysia, U. bifida and U. minutissima are pioneers of open disturbed wetland and are often locally abundant, although $U$. caerulea is increasingly rare. $U$. bifida is highly suited for acidic damp soils. Neither chemical nor organic fertilisation is necessary. It can be cultivated without having to modify bad drainage or liming the soil to increase $\mathrm{pH}$, therefore, it is a suitable alternative for small-scale herb cultivation on nutrient-poor, waterlogged soils.

\section{Conclusion}

Utricularia is an important component of nutrient-poor waterlogged habitats for which its special body plan and 
carnivorous habit are adapted. Being sensitive to microhydrological changes, water trophicity, biotic, and chemical pollutions, the presence or absence of common or rare Utricularia species could serve as indicator to predict the general health and recovery of many wet microhabitat types. The versatility of common species, on the other hand, gives them an edge over other medicinal herbs on acid, wet poor soils usually deemed not suitable for any crops.

\section{Acknowledgments}

Gratitude goes to the following for financial support: to the University of Malaya (Postgraduate Research Grant PS169/ 2008B/PS235/2009C), Forest Research Institute Malaysia (Flora of Peninsular Malaysia Project 01-04-01-0000 Khas 2; Research and Pre-commercialisation Grant GPP-TFBC1208-001), and Ministry of Natural Resource and Environment (Masters and Ph.D. Scholarship for the 9th Malaysian Plan); to the curators and keepers of the Herbaria of Kepong, Kew, Leiden and Singapore for specimen loans; to Dr. Ruth Kiew for invaluable comments.

\section{References}

[1] B. E. Juniper, R. J. Robins, and D. M. Joel, The Carnivorous Plants, Academic Press, London, UK, 1989.

[2] R. W. Jobson and E. C. Morris, "Feeding ecology of a carnivorous bladderwort (Utricularia uliginosa, Lentibulariaceae)," Austral Ecology, vol. 26, no. 6, pp. 680-691, 2001.

[3] L. Adamec, "Oxygen concentrations inside the traps of the carnivorous plants Utricularia and Genlisea (Lentibulariaceae)," Annals of Botany, vol. 100, no. 4, pp. 849-856, 2007.

[4] T. J. Givnish, E. L. Burkhardt, R. E. Happel, and J. D. Weintraub, "Carnivory in the bromeliad Brocchinia reducta, with a cost/benefit model for the general restriction of carnivorous plants to sunny, moist, nutrient-poor habitats," American Naturalist, vol. 124, no. 4, pp. 479-497, 1984.

[5] L. E. Friday, "Rapid turnover of traps in Utricularia vulgaris L.," Oecologia, vol. 80, no. 2, pp. 272-277, 1989.

[6] A.L. Bern, Studies on nitrogen and phosphorus uptake by the carnivorous bladderwort, Utricularia foliosa, in South Florida wetlands, M.S. thesis, Florida International University, Miami, Fla, USA, 1997.

[7] J. H. Richards, "Bladder function in Utricularia purpurea (Lentibulariaceae): Is carnivory important?" American Journal of Botany, vol. 88, no. 1, pp. 170-176, 2001.

[8] M. Y. Chew and N. W. Haron, "Utricularia (Lentibulariaceae) habitat diversity in Peninsular Malaysia and its implications for conservation," The Gardens' Bulletin Singapore, vol. 63, no. 1-2, pp. 451-464, 2011.

[9] L. S. L. Chua and L. G. Saw, Malaysia Plant Red List-Guide for Contributors, Forest Research Institute Malaysia, Kepong, Kuala Lumpur, 2006.

[10] T. C. Whitmore, An Introduction to Tropical Rain Forests, Oxford University Press, Oxford, UK, 1990.

[11] R. P. Lim, J. I. Furtado, and R. J. Morley, "General description of Tasik Bera," in Tasik Bera-The Ecology of a Freshwater Swamp. Monographiae Biologicae, J. I. Furtado and S. Mori, Eds., vol. 47, pp. 7-54, Dr. W. Junk Publishers, The Hague, The Netherlands, 1982. 

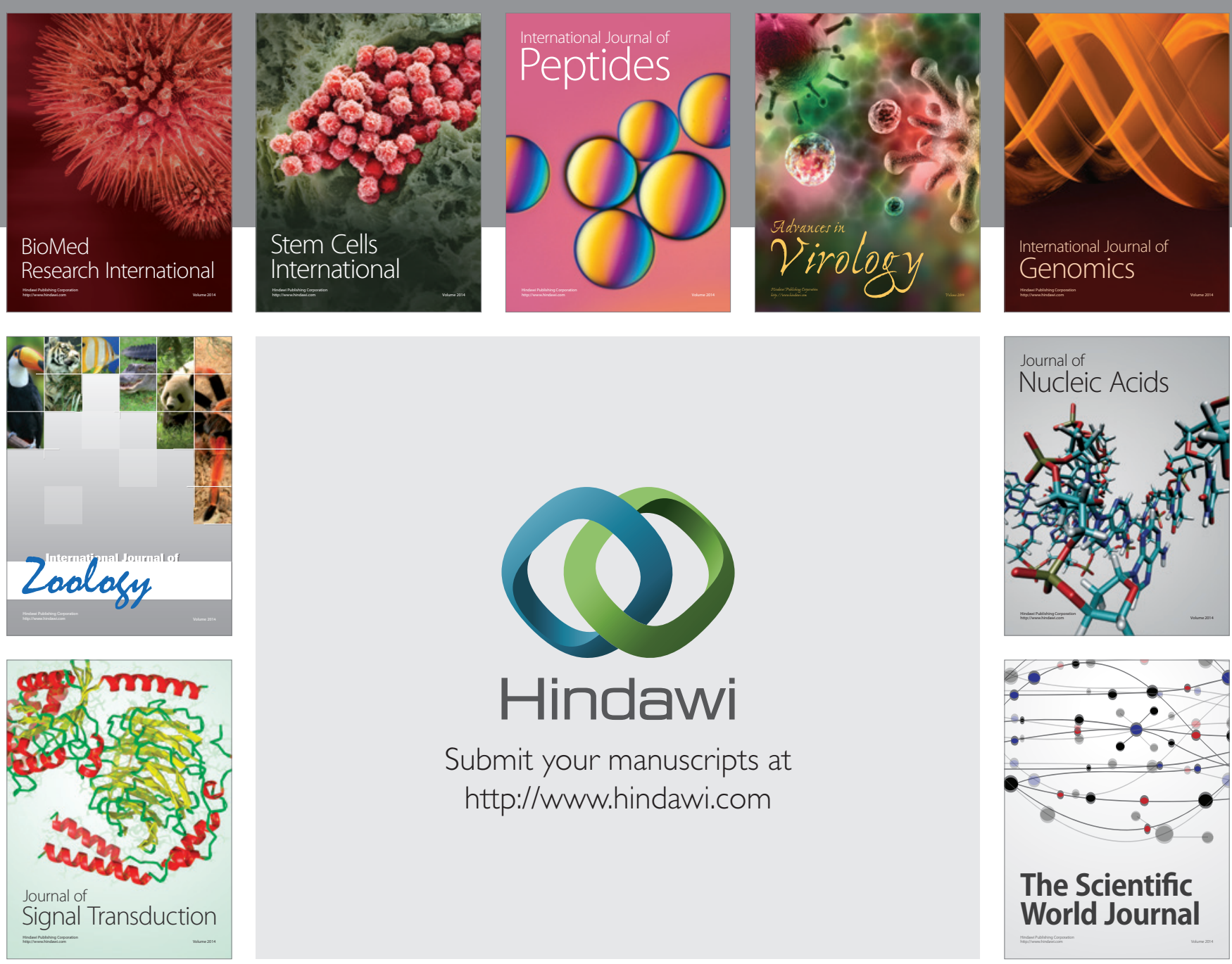

Submit your manuscripts at

http://www.hindawi.com
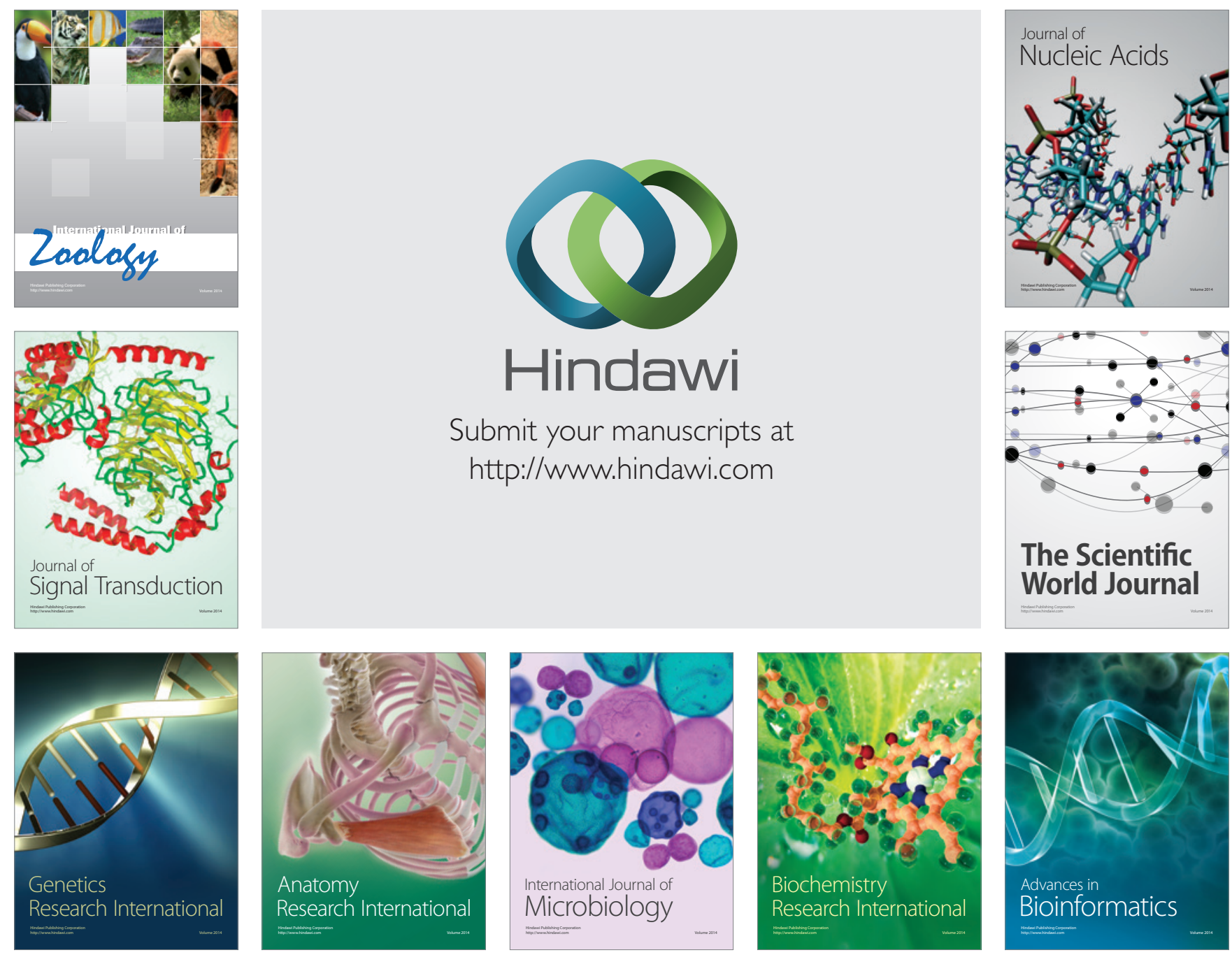

The Scientific World Journal
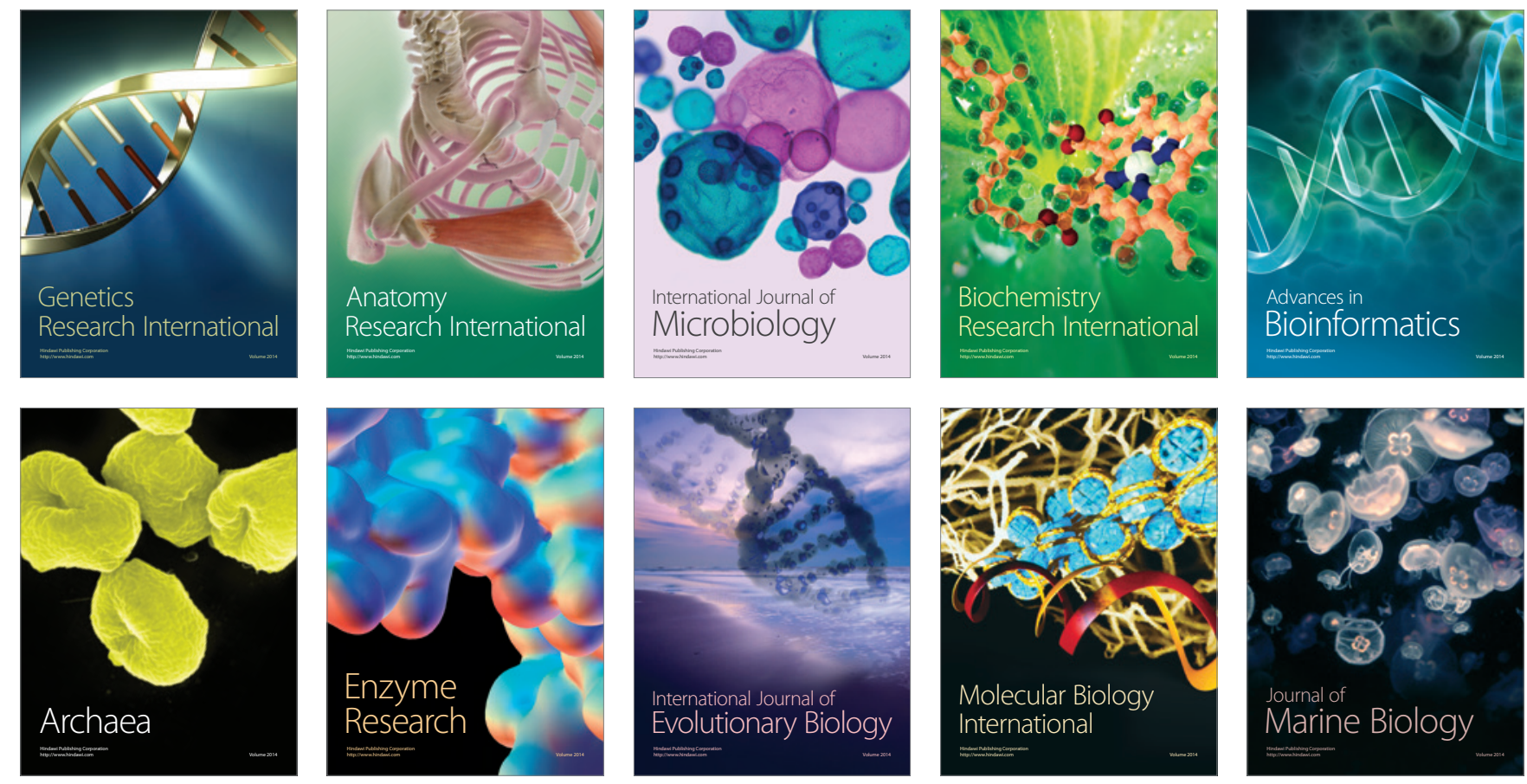